\title{
Intravenous and Subcutaneous Tramadol for Inguinal Herniorrhaphy: Comparative Study
}

\author{
Talita Oliveira Dias dos Santos 1, Tomaz Gonzalez Estrela 1, Vera Lucia Fernandes de Azevedo, TSA 2, \\ Onofre Eduardo Carvalho de Oliveira, TSA ${ }^{3}$, Gildásio Oliveira Júnior ${ }^{4}$, Gilvan da Silva Figueiredo, TSA ${ }^{3}$
}

\begin{abstract}
Summary: Santos TOD, Estrela TG, Azevedo VLF, Oliveira OEC, Oliveira Júnior G, Figueiredo GS - Intravenous and Subcutaneous Tramadol for Inguinal Herniorrhaphy: Comparative Study.
\end{abstract}

Background and objectives: Inguinal herniorrhaphy is one of the most common surgeries in men. Neuroaxis block is the anesthetic technique used more often and in the majority of the cases the patient is ready to be discharged from the hospital a few hours after the procedure, as long as satisfactory analgesia is present and nausea and vomiting are absent. Tramadol is an analgesic drug that can be used in postoperative analgesia, but it has important side effects, such as nausea and vomiting whose incidence can range from $0 \%$ to $50 \%$. The objective of the present study was to compare the incidence of nausea and vomiting and the quality of postoperative analgesia of subcutaneous and intravenous tramadol in patients undergoing inguinal herniorrhaphy.

Methods: This is a prospective study with 30 patients undergoing inguinal herniorrhaphy. Patients were divided into two groups: Group $C$ ( $n=15$ ) received $1.5 \mathrm{mg} \cdot \mathrm{kg}^{-1}$ of subcutaneous Tramadol, and Group V $(n=15)$ received $1.5 \mathrm{mg} \cdot \mathrm{kg}^{-1}$ of intravenous Tramadol. All patients underwent continuous epidural anesthesia with $0.5 \%$ levobupivacaine. Anthropometric data, quality of analgesia, and the development of postoperative nausea and vomiting in the first eight hours were recorded.

Results: Statistically significant differences were not observed between both groups for anthropometric data, quality of analgesia, and the development of nausea and vomiting.

Conclusions: The present study demonstrates the absence of statistically significant differences regarding the incidence of nausea and vomiting and quality of analgesia when using intravenous and subcutaneous Tramadol.

Keywords: ANALGESIA: Postoperative; DRUGS: tramadol; SURGERY, Abdominal: inguinal herniorrhaphy; COMPLICATIONS: nausea and vomit.

[Rev Bras Anestesiol 2010;60(5): 522-527] @Elsevier Editora Ltda.

\section{INTRODUCTION}

Inguinal herniorrhaphy is one of the most common surgeries in men; 70 thousand procedures are performed in the United States alone every year ${ }^{1}$. The majority of the studies on inguinal herniorrhaphy evaluate acute postoperative pain without considering the great incidence of chronic pain, which can reach $50 \%{ }^{2}$. Prevention and effective control of pain in the immediate postoperative period are determinant of a favorable evolution, therefore minimizing the possibility of chronic pain.

Received from Hospital Santo Antonio - CET Associação Obras Sociais Irmã Dulce Salvador $-B A$.

1. R3 of CET/SBA do Hospital Santo Antônio - Associação Obras Sociais Irmã Dulce, resident 2. Master's Degree in Anesthesiology, working on her Doctorate in Anesthesiology - FMB

- Unesp, Responsible for the CET/SBA do Hospital Santo Antônio - Associação Obras Sociais Irmã Dulce

3. Anesthesiologist, Instructor of the CET/SBA do Hospital Santo Antônio - Associação Obras Sociais Irmã Dulce

4. Anesthesiologist, Assisting Professor Northwestern University, Chicago - Illinois, USA

Submitted on February 23, 2010.

Approved on May 3, 2010.

Correspondence to:

Dra. Vera Lucia Fernandes de Azevedo

Rua Frederico Costa, 97, apt ${ }^{\circ}$ 1001. Edifício Pedra da Boa Vista

Brotas

40255350 - Salvador, BA, Brazil

E-mail: vlfazevedo@terra.com.br
Neuroaxis blockade is the anesthetic technique used more often in our service and, in the majority of the cases the patient is in condition to be discharged from the hospital a few hours after the procedure. The presence of satisfactory analgesia and absence of nausea and vomiting are fundamental for early ambulation and to avoid any delays in discharge from the hospital reducing costs and complications.

Tramadol, a 4-phenylpeperidine synthetic analogue of codeine, is a central acting analgesic with low affinity for opioid Mu receptors used especially to treat moderate pain. The inhibition of reuptake of the serotonin and noradrenaline blocks nociceptive impulses at the spine, promoting a significant contribution to the analgesic action of this drug 4 . The incidence of nausea and vomiting, which can range from $0 \%$ to $50 \%{ }^{4-7}$, associated with its use is one of the main inconvenient. The titrated use of this drug seems to make it more tolerable by patients ${ }^{3}$, and believing in this possibility, some anesthesiologists prefer the subcutaneous administration to avoid side effects and increase the duration of analgesia.

The objective of the present study was to compare the incidence of nausea and vomiting and the quality of postoperative analgesia of subcutaneous and intravenous tramadol in patients undergoing inguinal herniorrhaphy under spinal anesthesia. 


\section{METHODS}

After approval by the Ethics on Research Commission and signing of the informed consent, 30 male patients ages 18 to 60 years, physical status ASA I and II, undergoing unilateral non-relapsing inguinal hernia correction participated in this study. Patients with a history of allergies to any of the drugs used in this study, those who used antiemetic drugs 15 days before the procedure or monoamine oxidase inhibitors (MAOls) in the last 14 days, and patients with contraindications to the anesthetic technique proposed were excluded from this study.

All patients underwent inguinal herniorrhaphy with the technique used by the General Surgery department of the Hospital Santo Antônio. Spinal anesthesia was performed with the patient in the sitting position, puncture of the $\mathrm{L}_{2}-\mathrm{L}_{3}$ space with a \#17 Tuohy needle, a test-dose of $3 \mathrm{~mL}(60 \mathrm{mg})$ of $2 \%$ lidocaine with epinephrine 1:200,000 was administered, followed by the injection of $15 \mathrm{~mL}$ of $0.5 \%$ levobupivacaine (with epinephrine 1:200,000) and introduction of the epidural catheters. The same test-dose already mentioned followed by one third of the dose of levobupivacaine was used for complementary analgesia through the catheter. In case of hypotension (a reduction $>20 \%$ of baseline systolic BP) the rate of the infusion of crystalloids was increased and, if necessary, fractionated doses of $1 \mathrm{mg}$ of ethylephrine intravenously were administered until correction of the hypotension. All patients received dexamethasone $4 \mathrm{mg} \mathrm{IV}$, midazolam $0.1 \mathrm{mg} \cdot \mathrm{kg}^{-1} \mathrm{IV}$ with complementation, if necessary, for satisfactory sedation. At the end of the surgical procedure (skin closure) patients were randomly divided into two groups: Group C received subcutaneous tramadol $1.5 \mathrm{mg} \mathrm{kg}^{-1}$, while Group V received intravenous tramadol $1.5 \mathrm{mg} \cdot \mathrm{kg}^{-1}$ diluted in $100 \mathrm{~mL}$ of NS and administered over 5 to 10 minutes. All patients were transferred to the PACU where the first evaluations in the next 8 hours were performed regarding the presence of: I- nausea (according to the following scale: 0 absent; 1- mild, no need of pharmacologic treatment; 2- with the need of pharmacologic treatment; 3- resistant to pharmacologic treatment); II- vomiting (according to the following scale: 0- absent; 1- a single episode; 2- recurring episodes requiring pharmacologic treatment; 3 - resistant to pharmacologic treatment); III- quality of analgesia (according to the visual analogue scale: 0 - absence of pain; 10- worse pain possible) (Figure 1).

Nausea and vomiting were treated with metoclopramide 10 $\mathrm{mg}$ IV, and patients who complained of pain evaluated by the

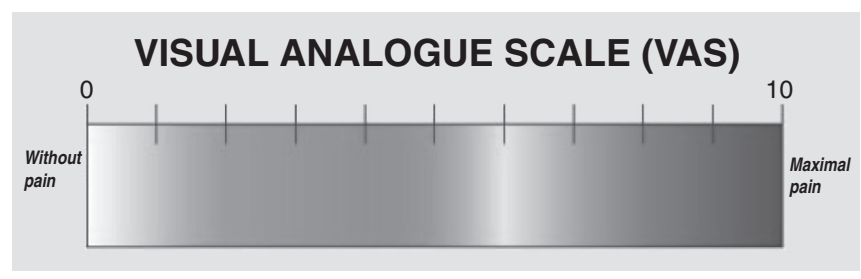

Figure 1. Visual Analogue Scale used to measure Pain. visual analogue scale with scores $>4$ were treated with ketoprofen $100 \mathrm{mg} \mathrm{IV}$.

Different professionals participated in patient selection, anesthesia, and postoperative evaluation.

Variables were compared by the Student $t$ test for independent samples (age, weight, height, and duration of the surgery), Fisher exact test (evaluation of physical status ASA and the presence of nausea and vomiting), and Twosample Wilcoxon rank-sum test (Mann-Whitney) (evaluation of pain).

\section{RESULTS}

Both groups were homogenous regarding anthropometric duration of the surgery, and physical status ASA (Table I).

Two patients in the V Group and two in the C Group developed nausea, without vomiting, which improved after the administration of metoclopramide, $10 \mathrm{mg}$ IV (Table II).

When the quality of analgesia in both groups was compared, 7 patients -3 in the C Group and 4 in the V Group (Table III) - reported pain greater than 4, median of 2, in the Visual Analogue Scale, without statistically significant difference. Those patients were treated with ketoprofen $100 \mathrm{mg} \mathrm{IV}$, with satisfactory response.

Table I - Anthropometrics Data, Surgery Duration, and Physical Status

\begin{tabular}{llll}
\hline & Gruop V & Gruop C & p \\
\hline Age (years) * & $40.2 \pm 12.8$ & $44.2 \pm 12.9$ & 0.36 \\
Weight $(\mathrm{kg}){ }^{*}$ & $70 \pm 11.3$ & $68 \pm 9.8$ & 0.5 \\
Hight $(\mathrm{m}){ }^{*}$ & $1.69 \pm 0.07$ & $1.64 \pm 0.09$ & 0.13 \\
& & & \\
$\begin{array}{l}\text { Surgery duration (min) * } \\
\text { Physical status }\end{array}$ & $98 \pm 25.3$ & $116 \pm 36.9$ & 0.9 \\
\multicolumn{1}{c}{ ASA I } & $12(80 \%)$ & $12(80 \%)$ & \\
ASA II & $3(20 \%)$ & $3(20 \%)$ & \\
\hline
\end{tabular}

* Values expressed on Mean \pm Standard deviation.

Table II - Frequency of Postoperative Nausea and Vomiting

\begin{tabular}{llll}
\hline & Gruop V & Gruop C & $\mathrm{p}$ \\
\hline Nausea & $2(13)$ & $2(13)$ & 1,0 \\
Vomiting & $0(15)$ & $0(15)$ & 1,0 \\
\hline
\end{tabular}

Table III - Median and 1st and 3rd Quartile Regarding Postoperative Pain

\begin{tabular}{llll}
\hline & Gruop V & Gruop C & $p$ \\
\hline Postoperative pain & $2[0-3]$ & $2[0-5]$ & 0.9 \\
\hline
\end{tabular}

${ }^{*}$ median [ 25\%-75\% interquartile]. 


\section{DISCUSSION}

Up to $62 \%$ of the patients might present moderate to severe pain in the postoperative period of inguinal herniorrhaphy ${ }^{8}$, and the doses of tramadol usually administered can be ineffective when used isolated in those situations ${ }^{9}$. Residual analgesia of the epidural blockade with levobupivacaine associated with analgesia with tramadol, both intravenous and subcutaneous, were enough to promote adequate analgesia during the study period.

Despite the questionable effect of $10 \mathrm{mg}$ of metoclopramide in the prevention and treatment of postoperative nausea and vomiting ${ }^{10}$, this drug was chosen because ondansetron can potentially interfere with the analgesic action of tramadol by blocking serotonergic pathways ${ }^{5,11}$, and the possibility of prolonged sedation associated to droperidol could delay the discharge of patients.

The variable incidence of nausea and vomiting associated with tramadol reported in the literature ${ }^{4-7}$ seems to be related to the administration route and doses used. Altunkaya $\mathrm{H}$ et al. used $2 \mathrm{mg} \mathrm{kg}^{-1}$ of tramadol and only one out of 20 patients developed nausea and prolonged analgesia, over 24 hours of evaluation in the postoperative period of lipoma excision ${ }^{4}$. The same study also showed potential local analgesic effect of this drug.

This study concluded that a difference between intravenous and subcutaneous tramadol regarding the incidence of nausea and vomiting and the quality of analgesia was not observed during the 8 hours following its administration. 
06. Zeidan A, Kassem R Nahleh $\mathrm{N}$ et al - Intraarticular Tramadol-bupivacaine combination prolongs the duration of postoperative analgesia after arthroscopic knee surgery. Anesth Analg, 2008;107:292-299.

07. Unlugenc $\mathrm{H}$, Vardar MA, MD, Tetiker S - A comparative study of the analgesic effect of patient-controlled morphine, pethidine, and tramadol for postoperative pain management after abdominal hysterectomy. Anesth Analg, 2008;106:309-312.

08. Rawal N, Hylander J, Nydahl PA et al. - Suryey of postoperative analgesia following ambulatory surgery. Acta Anaesthesiol Scand, 1997;41:1017-1022.

09. Thévenin A, Beloeil H. Blanie A et al - The limited efficacy of tramadol in postoperative patients: a study of ED 80 using the continual reassessment method. Anesth Analg, 2008;106:622-627.

10. Gan TJ, Meyer TA et al. - Society for ambulatory anesthesia guidelines for the management of postoperative nausea and vomiting. anesth analg, 2007;105:1615-1628.

11. Arcioni R, Rocca MD, Romano $S$ et al - Ondansetron inhibits the analgesic effects of tramadol: a possible 5-ht3 spinal receptor involvement in acute pain in humans. Anesth Analg, 2002;94:1553-1557.

Resumen: Santos TOD, Estrela TG, Azevedo VLF, Oliveira OEC, Oliveira Júnior G, Figueiredo GS - Uso del Tramadol Venoso y Subcutáneo en Herniorrafía Inguinal: Estudio Comparativo.

Justificativa y objetivos: La herniorrafía inguinal es una de las cirugías más realizadas en el hombre. El bloqueo del neuro eje es la técnica anestésica más utilizada y en la mayoría de los casos, el paciente está en condiciones de recibir el alta algunas horas después del procedimiento, siempre que presente analgesia satisfactoria y la ausencia de náuseas y vómitos. El tramadol es un fármaco analgésico que puede ser utilizado para la analgesia postoperatoria, pero que presenta, como importantes efectos colaterales, náuseas y vómitos, y su incidencia puede variar de $0 \%$ a $50 \%$, dependiendo del uso. El objetivo de este estudio fue comparar la incidencia de náuseas y vómitos y la calidad de la analgesia postoperatoria del tramadol por la vía subcutánea y endovenosa en pacientes sometidos a la herniorrafía inguinal.

\section{REFERÊNCIAS / REFERENCES}

01. Rutkow IM, Robbins AW - Aspectos demográficos classificatórios e socioeconômicos do reparo herniário nos Estados Unidos da América. Clin Cir am Norte, 1993;3:433-438.

02. Poobalan AS, Bruce J, Smith WCS et al - A Review of Chronic Pain After Inguinal Herniorrhaphy. The Clinical Journal of Pain, 2003;19: 48-54.

03. Dayer P, Desmeules J Collart L - Pharmacology of tramadol - drugs, 1997;53(Suppl2):18-24.

04. Altunkay $\mathrm{H}$, Ozer $\mathrm{Y}$, Kargi $\mathrm{E}$ et al - The postoperative analgesic effect of tramadol when used as subcutaneous local anesthetic. Anesth Analg, 2004;99:1461-1464.

05. De Witte JL, Schoenmaekers B Sessler DI et al - The analgesic efficacy of tramadol is impaired by concurrent administration of Ondansetron. Anesth Analg, 2001;92:1319-1321.
Métodos: Estudio prospectivo con 30 pacientes sometidos a la herniorrafía inguinal. Se dividieron en dos grupos: Grupo $C(n=15)$ que recibió Tramadol 1,5 mg. $\mathrm{kg}^{-1}$ subcutáneo y el Grupo V $(\mathrm{n}=15)$ que recibió Tramadol $1,5 \mathrm{mg} \cdot \mathrm{kg}^{-1}$ endovenoso. A todos los pacientes se les practicó la anestesia epidural continua con levobupivacaína a 0,5\%. Fueron registrados los datos antropométricos, la calidad de la analgesia y la incidencia de náuseas y vómitos en el postoperatorio (en las primeras ocho horas).

Resultados: No hubo diferencia estadística entre los grupos con relación a los datos antropométricos, calidad de la analgesia e incidencia de náuseas y vómitos.

Conclusiones: En este estudio llegamos a la conclusión de que no existe diferencia estadísticamente significante cuanto a la incidencia de náuseas y vómitos y a la calidad de la analgesia cuando se utiliza el tramadol por vía venosa y subcutánea. 